\title{
Synthesis and Antiproliferative Activity of 1-(4-(1H-Indol-3-Yl)-6-(4- Methoxyphenyl)Pyrimidin-2-yl)Hydrazine and Its Pyrazolo Pyrimidine Derivatives
}

\author{
Ekhlass Nassar ${ }^{1^{*}}$, Yaser A El-Badry ${ }^{2,3}$, Afaf MM Eltoukhy ${ }^{1}$ and Rezek R Ayyad ${ }^{4,5}$ \\ ${ }^{1}$ Organic Chemistry Department, Faculty of Women's for Arts, Science and Education, Ain Shams University, Cairo, Egypt \\ ${ }^{2}$ Organic Chemistry Lab, Faculty of Specific Education, Ain Shams University, 11566 Abbasseya, Cairo, Egypt \\ ${ }^{3}$ Organic Chemistry Lab, Faculty of Science, Taif University, Khurma, Kingdom of Saudi Arabia \\ ${ }^{4}$ Pharmaceutical Chemistry Department, Faculty of Pharmacy, Al-Azhar University, Cairo, Egypt \\ ${ }^{5}$ Medicinal Chemistry Department, Faculty of Pharmacy, Delta University, Gamasa Ad-dakahlia, Egypt
}

\begin{abstract}
The target compounds 1-(4-(1H-indol-3-yl)-6-(4-methoxyphenyl)pyrimidin-2-yl)hydrazine $(5)$ was synthesized by reacting 6-(1H-Indol-3-yl)-4-(4-methoxyphenyl)pyrimidine-2(1H)-thione 4 with hydrazine hydrate. Compound 5 was used as a precursor for the synthesis of new pyrazolo pyrimidine derivatives 6-9. Moreover, the 5 -amino- $1 H$-pyrazole4-carbonitrile derivative 6 was then converted into another set of novel compounds 10-14. On the other hand a series of transformations were carried out using the newly synthesized 1-(4-(1H-indol-3-yl)-6-(4-methoxyphenyl) pyrimidin2-yl)-1H-pyrazolo[3,4-d]pyrimidin-4(5H)-one (11) to afford the pyrazolo pyrimidine derivatives 15-18. Antiproliferatve activities for some of the newly synthesized compounds were evaluated.
\end{abstract}

Keywords: Pyrazolopyrimidine; Indole aldehyde; Chalcone; Antiproliferative activity; Triazin-4-one: 5-aminopyrazole

\section{Introduction}

Chalcones constitute an important group of natural products and are the precursors of flavonoids, isoflavonoids and many synthetic heterocycles of different biological activities including pyrimidines, pyrazolines, pyrazolopyrimidines and diazepines [1-5].

Chemically, chalcones are characterized by their easy synthesis by Claisen-Schmidt condensation in good yields and the presence of the $\alpha, \beta$ unsaturated carbonyl system linked to two aromatic rings which encourage the chalcones cyclization through Michael addition to give interesting heterocyclic compounds which exhibit antitumor [6,7], antimitotic [8], antimutagenic [9] antibacterial [10], antiviral [11], antiinflammatory [12], antiulcerative [13] and hepatoprotective [14]. In the present work we have been synthesized a series of novel heterocyclic compounds derived from a previous synthesized chalcone compound [1]. The new compounds were screened for their antiproliferative activities.

\section{Experimental}

\section{General}

Melting points were measured on a digital Electrothermal 9100 apparatus (Kleinfeld, Gehrden, Germany) and are uncorrected. FTIR spectra $(\mathrm{KBr})$ were obtained on a Nicolet 205 spectrophotometer (Nicolet, Madison, WI, USA). The ${ }^{1} \mathrm{H}$ NMR spectra were recorded on a Varian Mercury VX-300 NMR spectrometer (Varian inc., Palo Alto, CA, USA). Chemical shifts are expressed in $\delta$ values. The mass spectra were recorded on a Shimadzu GCMS-QP-1000EX mass spectrometer (Shimadzu, Kyoto, Japan) at $70 \mathrm{eV}$. Elemental analysis were carried out at the Micro-analytical Center of Cairo University. All reactions were routinely followed by TLC.

3-(2-hydrazinyl-6-(4-methoxyphenyl)pyrimidin-4-yl)-1Hindole (5)

The hydrazino-pyrimidine derivative $\mathbf{5}$ was prepared by reacting compound 4 [1] (10.0 $\mathrm{mmol})$ with hydrazine hydrate $(10.0$ $\mathrm{mmol}$ ) catalyzed by acetic acid (5 drops) in refluxing ethanol for 6 h. Evaporation of alcohol and recrystallization with ethanol gave compound 5 as pale brown crystals mp $160-2^{\circ} \mathrm{C}$, yield $80 \%$ (element test for the product confirmed the disappearance of sulfur). IR: $v_{\max }$ I $\mathrm{cm}^{-1} 3212\left(\mathrm{NH}_{2}\right), 3184(\mathrm{NH}), 3109(\mathrm{NH}), 1618(\mathrm{C}=\mathrm{N}), 1576(\mathrm{C}=\mathrm{N}) .{ }^{1} \mathrm{H}$ MR (DMSO-d $\mathrm{d}_{6}$ ): $\delta 3.78\left(\mathrm{~s}, 3 \mathrm{H}, \mathrm{OCH}_{3}\right), 7.05-7.3$ (m, $4 \mathrm{H}, \mathrm{Ar} \mathrm{H}$ 's), 7.52 (d, $2 \mathrm{H}, J=8.8 \mathrm{~Hz}$, Ar-H), 7.94 (s, $1 \mathrm{H}$, pyrimidin), 8.4 (d, $2 \mathrm{H}, J=8.8 \mathrm{~Hz}$, Ar-H's), 8.78 (s, 1H, indole), 8.93-8.95 (brs, 3H, $\mathrm{D}_{2} \mathrm{O}$ Exch., $\mathrm{NH}_{2}, \mathrm{NH}$ ), 11.65 (s, 1H, $\mathrm{D}_{2} \mathrm{O}$ Exch., indole NH). MS: $\mathrm{m} / \mathrm{z}(\%) 331\left[\mathrm{M}^{+}, 5.08\right]$. Anal. Calcd. For $\mathrm{C}_{19} \mathrm{H}_{17} \mathrm{~N}_{5} \mathrm{O}$ (331.37): C, 68.87; H, 5.17; N, 21.13. Found: C, 68.76; H, 5.35; N, 21.30 .

1-(4-(1H-indol-3-yl)-6-(4-methoxyphenyl)pyrimidin-2-yl)5-amino-1H-pyrazole-4-carbonitrile (6)

To a solution of compound $5(10 \mathrm{mmol})$ in ethanol $(30 \mathrm{~mL})$, ethoxymethylene malononitrile $(10 \mathrm{mmol})$, was added. The reaction mixture was heated under reflux condition for $8 \mathrm{~h}$. Then the formed precipitate was filtered and recrystallized from ethanol to give pale brown crystals of compound $6 \mathrm{mp} 174-6^{\circ} \mathrm{C}$, yield $76 \%$ IR: $v_{\max } / \mathrm{cm}^{-1}$ $3356\left(\mathrm{NH}_{2}\right), 3164(\mathrm{NH}), 2224(\mathrm{C} \equiv \mathrm{N}) .{ }^{1} \mathrm{H}$ NMR $\left(\mathrm{DMSO}-\mathrm{d}_{6}\right): \delta 3.49(\mathrm{~s}$, $3 \mathrm{H}, \mathrm{OCH}_{3}$ ), 7.01-7.27 (m, 4H, Ar H's), 7.46 (d, 2H, J=8.6 Hz, Ar-H), 7.87 (s, $1 \mathrm{H}$, pyrazole), 8.28 (s, $1 \mathrm{H}$, indole), 8.30 (d, $2 \mathrm{H}, J=8.6 \mathrm{~Hz}$, ArH's), 8.56 (s, $1 \mathrm{H}$, pyrimidin), 8.85 (s, 2H, $\mathrm{D}_{2} \mathrm{O}$ Exch., $\mathrm{NH}_{2}$ ), 11.66 (s, $1 \mathrm{H}, \mathrm{D}_{2} \mathrm{O}$ Exch., indole NH). MS: $\mathrm{m} / \mathrm{z}(\%) 407\left[\mathrm{M}^{+}, 0.39\right]$. Anal. Calcd. For $\mathrm{C}_{23} \mathrm{H}_{17} \mathrm{~N}_{7} \mathrm{O}$ (407.43): C, 67.80; H, 4.21; N, 24.06. Found: C, 67.66; $\mathrm{H}, 4.38 ; \mathrm{N}, 24.25$.

\section{3-(2-(3,5-dimethyl-1H-pyrazol-1-yl)-6-(4-methoxyphenyl) pyrimidin-4-yl)-1H-indole (7)}

A solution of compound 5 (10 $\mathrm{mmol})$ in absolute ethanol and

*Corresponding author: Ekhlass Nassar, Organic Chemistry Department, Faculty of Women's for Arts, Science and Education, Ain Shams University, Cairo, Egypt, E-mail: ekhlass_nassar@hotmail.com

Received March 17, 2016; Accepted April 07, 2016; Published April 14, 2016

Citation: Nassar E, El-Badry YA, Eltoukhy AMM, Ayyad RR (2016) Synthesis and Antiproliferative Activity of 1-(4-(1H-Indol-3-Yl)-6-(4-Methoxyphenyl)Pyrimidin-2-yl) Hydrazine and Its Pyrazolo Pyrimidine Derivatives. Med chem (Los Angeles) 6: 224-233. doi:10.4172/2161-0444.1000350

Copyright: $\odot 2016$ Nassar E, et al. This is an open-access article distributed under the terms of the Creative Commons Attribution License, which permits unrestricted use, distribution, and reproduction in any medium, provided the original author and source are credited. 
acetylacetone $(10 \mathrm{mmol})$ was heated at reflux temperature for $5 \mathrm{~h}$. The mixture was evaporated under reduced pressure, and the obtained product was recrystallized from ethanol to afford pale brown crystals of pyrazolo pyrimidine derivative $7 \mathrm{mp} 187-9^{\circ} \mathrm{C}$, yield $70 \%$ IR: $v_{\max } / \mathrm{cm}^{-1}$ $3170(\mathrm{NH}), 3109$ (CH-Ar.), $1634(\mathrm{C}=\mathrm{N}), 1600(\mathrm{C}=\mathrm{N}), 1574(\mathrm{C}=\mathrm{N}) .{ }^{1} \mathrm{H}$ NMR (DMSO-d $)$ ) $\delta 2.3\left(\mathrm{~s}, 3 \mathrm{H}, \mathrm{CH}_{3}\right), 2.58\left(\mathrm{~s}, 3 \mathrm{H}, \mathrm{CH}_{3}\right), 3.83(\mathrm{~s}, 3 \mathrm{H}$, $\left.\mathrm{OCH}_{3}\right), 6.99(\mathrm{~s}, 1 \mathrm{H}$, pyrazole), 7.17-7.26 (m, $4 \mathrm{H}, \mathrm{Ar}-\mathrm{H}$ 's), 7.53 (d, $2 \mathrm{H}$, $J=8.6 \mathrm{~Hz}, \mathrm{Ar}-\mathrm{H}$ 's), 7.94 (s, $1 \mathrm{H}$, indole), 8.38 (d, $2 \mathrm{H}, J=8.6 \mathrm{~Hz}, \mathrm{Ar}-\mathrm{H} ' \mathrm{~s})$, 8.94 (s, 1H, pyrimidine), 11.7 (s, $1 \mathrm{H}, \mathrm{D}_{2} \mathrm{O}$ Exch., indole $\left.\mathrm{NH}\right) . \mathrm{MS}: \mathrm{m} / \mathrm{z}$ (\%) $395\left[\mathrm{M}^{+}, 2.0\right]$. Anal. Calcd. For $\mathrm{C}_{24}^{2} \mathrm{H}_{21} \mathrm{~N}_{5} \mathrm{O}$ (395.46): C, 72.89; H, $5.35 ; \mathrm{N}, 17.71$. Found: C, 72.70; H, 5.52; N, 17.90

\section{1-(4-(1H-indol-3-yl)-6-(4-methoxyphenyl)pyrimidin-2-yl)-} 3-methyl-1H-pyrazol-5(4H)-one (8)

Compound $5(10 \mathrm{mmol})$ and ethyl acetoacetate $(10 \mathrm{mmol})$ in acetic acid $(30 \mathrm{~mL})$ was heated at reflux temperature for $6 \mathrm{~h}$. The mixture was poured into ice cold water and the obtained product washed with ice cold water, dried and recrystallized from ethanol to afford pale brown crystals of $8 \mathrm{mp} 210-2^{\circ} \mathrm{C}$, yield 72\% IR: $v_{\max } / \mathrm{cm}^{-1} 3216(\mathrm{NH}), 1718$ $(\mathrm{C}=\mathrm{O}) .{ }^{1} \mathrm{H}$ NMR (DMSO-d $\left.\mathrm{d}_{6}\right): \delta 1.22\left(\mathrm{~s}, 3 \mathrm{H}, \mathrm{CH}_{3}\right), 2.24\left(\mathrm{~s}, 2 \mathrm{H}, \mathrm{CH}_{2}\right.$, pyrazol), 3.83 (s, $3 \mathrm{H}, \mathrm{OCH}_{3}$ ), 7.02-7.23 (m, $4 \mathrm{H}, \mathrm{Ar} \mathrm{H}$ 's), 7.52 (d, $2 \mathrm{H}$, $J=8.6 \mathrm{~Hz}, \mathrm{Ar}-\mathrm{H}$ 's), 7.9 (s, $1 \mathrm{H}$, indole), 8.4 (d, $2 \mathrm{H}, J=8.6 \mathrm{~Hz}, \mathrm{Ar}-\mathrm{H}$ 's), 8.95 (s, $1 \mathrm{H}$, pyrimidin), 11.72 (s, $1 \mathrm{H}, \mathrm{D}_{2} \mathrm{O}$ Exch., indole $\left.\mathrm{NH}\right) . \mathrm{MS}: \mathrm{m} / \mathrm{z}(\%)$ 397 [ $\left.\mathrm{M}^{+}, 54\right]$. Anal. Calcd. For $\mathrm{C}_{23} \mathrm{H}_{19} \mathrm{~N}_{5} \mathrm{O}_{2}$ (397.43): C, 69.51; H, 4.82; N, 17.62. Found: C, 69.66; H, 4.64; N, 17.80 .

1-(4-(1H-indol-3-yl)-6-(4-methoxyphenyl)pyrimidin-2-yl)3,4-dimethylpyrano[2,3-c]pyrazol-6(1H)-one (9)

Compound $5(10 \mathrm{mmol})$ and ethyl acetoacetate in excess $(30 \mathrm{~mL})$ was heated at reflux temperature for $6 \mathrm{~h}$. The mixture was poured into ice cold water and the obtained product washed with water, dried and recrystallized from ethanol to give pale brown crystals of the pyrazolone compound $9 \mathrm{mp} 188-0^{\circ} \mathrm{C}$, yield 72\% IR: $v_{\max } / \mathrm{cm}^{-1} 3367(\mathrm{NH}), 1715$ $(\mathrm{C}=\mathrm{O}) .{ }^{1} \mathrm{H}$ NMR (DMSO-d $): \delta 2.25\left(\mathrm{~s}, 3 \mathrm{H}, \mathrm{CH}_{3}\right), 2.32\left(\mathrm{~s}, 3 \mathrm{H}, \mathrm{CH}_{3}\right)$, $3.80\left(\mathrm{~s}, 3 \mathrm{H}, \mathrm{OCH}_{3}\right), 5.60$ (s, $1 \mathrm{H}$, pyranone), 6.99-7.26 (m, $4 \mathrm{H}, \mathrm{Ar} \mathrm{H}$ 's), 7.38 (d, $2 \mathrm{H}, J=8.8 \mathrm{~Hz}$, Ar-H's), 7.42 (d, 2H, J=8.8 Hz, Ar-H's), 8.11 (s, $1 \mathrm{H}$, indole), 8.70 (s, $1 \mathrm{H}$, pyrimidin), 10.41 (s, $1 \mathrm{H}, \mathrm{D}_{2} \mathrm{O}$ Exch., indole $\mathrm{NH})$. MS: $\mathrm{m} / \mathrm{z}(\%) 463\left[\mathrm{M}^{+}, 8.6\right]$. Anal. Calcd. For $\mathrm{C}_{27} \mathrm{H}_{21} \mathrm{~N}_{5} \mathrm{O}_{3}(463.49)$ : C, 69.97; H, 4.57; N, 15.11. Found: C, 69.78; H, 4.72; N, 15.30.

1-(4-(1H-indol-3-yl)-6-(4-methoxyphenyl)pyrimidin-2-yl)1H-pyrazolo[3,4-d]pyrimidin-4-amine (10)

A mixture of compound $6(10 \mathrm{mmol})$ and formamide $(30 \mathrm{ml})$ was heated at $150^{\circ} \mathrm{C}$ for $3 \mathrm{~h}$. The reaction mixture was cooled and poured into water. The formed solid was filtered off, dried and recrystallized from ethanol to afford the pyrazolo pyrimidine derivative 10 as pale brown crystals $152-4^{\circ} \mathrm{C}$, yield $68 \%$ IR: $v_{\max } / \mathrm{cm}^{-1} 3389\left(\mathrm{NH}_{2}\right), 3190$ (NH). ${ }^{1} \mathrm{H}$ NMR (DMSO-d $): \delta 3.89\left(\mathrm{~s}, 3 \mathrm{H}, \mathrm{OCH}_{3}\right), 6.93-7.13(\mathrm{~m}, 4 \mathrm{H}, \mathrm{Ar}$ H's), 7.23 (d, 2H, J=8.7 Hz, Ar-H's), 7.35 (d, 2H, J=8.7 Hz, Ar-H's), 7.93 (s,1H, $\mathrm{D}_{2} \mathrm{O}$ Exch., $\mathrm{NH}_{2}$ ), 8.01 (s, $1 \mathrm{H}$, prazole), 8.07 (s, $1 \mathrm{H}$, pyrimidine), 8.12 (s, $1 \mathrm{H}$, indole), 8.2 (s, $1 \mathrm{H}$, pyrimidin), 10.82 (s, 1H, $\mathrm{D}_{2} \mathrm{O}$ Exch., indole NH). MS: $\mathrm{m} / \mathrm{z}(\%) 434\left[\mathrm{M}^{+}, 24.1\right]$. Anal. Calcd. For $\mathrm{C}_{24} \mathrm{H}_{18} \mathrm{~N}_{8} \mathrm{O}$ (434.45): C, 66.35; H, 4.18; N, 25.79. Found: C, 66.50; H, 4.32; N, 25.61 .

1-(4-(1H-indol-3-yl)-6-(4-methoxyphenyl)pyrimidin-2-yl)1H-pyrazolo[3,4-d]pyrimidin-4(5H)-one (11)

\section{Synthesis of compound (11):}

- Method A: Compound 6 (10 mmol) was heated under reflux conditions in formic acid $(30 \mathrm{ml}, 85 \%)$ for $8 \mathrm{~h}$. The reaction mixture was cooled and poured into ice cold water. The formed solid was filtered off, dried, and recrystallized from dimethylformamide to give 11 .

- Method B: Compound 12 (10 mmol) was heated under reflux temperature in triethyl orthoformate $(30 \mathrm{ml})$ for $10 \mathrm{~h}$. The product which separated on cooling was filtered off, washed with ethanol, dried and recrystallized from dimethylformamide to give pale brown crystals of compound $11 \mathrm{mp} 190-2^{\circ} \mathrm{C}$, yield 65\% IR: $v_{\max } / \mathrm{cm}^{-1} 3398(\mathrm{NH}), 3177(\mathrm{NH}), 1665(\mathrm{C}=\mathrm{O}) .{ }^{1} \mathrm{H}$ NMR (DMSO-d $)$ ): $\delta 3.87\left(\mathrm{~s}, 3 \mathrm{H}, \mathrm{OCH}_{3}\right), 7.10-7.15(\mathrm{~m}, 4 \mathrm{H}, \mathrm{Ar}-$ H's), 7.35 (d, 2H, J=8.6 Hz, Ar-H's), 7.40 (d, 2H, J=8.6 Hz, Ar$\left.\mathrm{H}^{\prime} \mathrm{s}\right), 7.45$ (s,1H, D O Exch., NH), 7.50 (s, 1H, prazole), 8.11 (s, $1 \mathrm{H}$, indole), 8.18 (s, $1 \mathrm{H}$, pyrimidine), 8.21 (s, $1 \mathrm{H}$, pyrimidin), 10.99 (s, 1H, D O Exch., indole NH). MS: m/z (\%) $435\left[\mathrm{M}^{+}\right.$, 63]. Anal. Calcd. For $\mathrm{C}_{24} \mathrm{H}_{17} \mathrm{~N}_{7} \mathrm{O}_{2}$ (435.44): C, 66.20; H, 3.94; N, 22.52. Found: C, 66.38; H, 3.76; N, 22.71.

1-(4-(1H-indol-3-yl)-6-(4-methoxyphenyl)pyrimidin-2-yl)5-amino-1H-pyrazole-4-carboxamide (12)

To (10 m mol) of compound $\mathbf{6}$, cold concentrated sulphuric acid $(10 \mathrm{ml})$, was added portion wise with ice bath cooling and stirring. After 10 minutes, the ice bath was removed and the mixture was stirred for an additional 15 minutes. The resulting pale yellow solution was carefully poured onto crushed ice and the resulting precipitate was collected, washed with water, dried and recrystallized from dioxane to give yellow crystals of the pyrazolo carboxamide $12 \mathrm{mp} 167-9^{\circ} \mathrm{C}$, yield 65\% IR: $v_{\text {max }} / \mathrm{cm}-13398\left(\mathrm{NH}_{2}\right), 3267\left(\mathrm{NH}_{2}\right), 3114(\mathrm{NH}), 1640(\mathrm{C}=\mathrm{O})$. ${ }^{1} \mathrm{H}$ NMR (DMSO-d $)$ ): $\delta 3.82$ (s, 3H, $\mathrm{OCH}_{3}$ ), 7.25-7.29 (m, 4H, Ar-H's), 7.49 (d, 2H, J=8.8 Hz, Ar-H's), 8.05 (d, 2H, J=8.8 Hz, Ar-H's), 8.29 (s, $2 \mathrm{H}, \mathrm{D}_{2} \mathrm{O}$ Exch., $\mathrm{NH}_{2}$ ), 8.41 (s, $1 \mathrm{H}$, prazole), 8.57 (s, $1 \mathrm{H}$, indole), 8.69 (s, $1 \mathrm{H}$, pyrimidin), 8.74 (s, $2 \mathrm{H}, \mathrm{D}_{2} \mathrm{O}$ Exch., $\mathrm{NH}_{2}$ ), 12.72 (s, $1 \mathrm{H}, \mathrm{D}_{2} \mathrm{O}$ Exch., indole $\mathrm{NH})$. MS: $\mathrm{m} / \mathrm{z}(\%) 425\left[\mathrm{M}^{+}, 1.03\right]$. Anal. Calcd. For $\mathrm{C}_{23} \mathrm{H}_{19} \mathrm{~N}_{7} \mathrm{O}_{2}$ (425.44): C, 64.93; H, 4.50; N, 23.05. Found: C, 64.70; H, 4.70; N, 23.26.

7-(4-(1H-indol-3-yl)-6-(4-methoxyphenyl)pyrimidin-2-yl)$3 \mathrm{H}$-pyrazolo[3,4-d] $[1,2,3]$ triazin- $4(7 \mathrm{H})$-one $(13)$

To a suspended solution of compound $12(10 \mathrm{~m} \mathrm{~mol})$ in concentrated hydrochloric acid $(30 \mathrm{ml})$ at $0-5^{\circ} \mathrm{C}$, a solution of sodium nitrite $(3.00 \mathrm{~g})$ in water $(5 \mathrm{ml})$ was added over 20 minutes. After $2 \mathrm{~h}$ of stirring at room temperature the foamy mixture was filtered off. The resulting solid was washed with ice cold water, dried and recrystallized from ethanol to give pale brown crystals of compound $13 \mathrm{mp} 148-0^{\circ} \mathrm{C}$, yield $64 \% \mathrm{IR}$ : $v_{\max } / \mathrm{cm}^{-1} 3230(\mathrm{NH}), 3118(\mathrm{NH}), 1685(\mathrm{C}=\mathrm{O}) .{ }^{1} \mathrm{H}$ NMR $\left(\mathrm{DMSO}-\mathrm{d}_{6}\right): \delta$ 3.84 (s, $\left.3 \mathrm{H}, \mathrm{OCH}_{3}\right), 7.15-7.26(\mathrm{~m}, 4 \mathrm{H}, \mathrm{Ar} \mathrm{H}$ 's), 7.31 (d, $2 \mathrm{H}, J=8.6 \mathrm{~Hz}$, Ar-H's), 7.65 (d, 2H, J=8.6 Hz, Ar-H's), 8.21 (s, 1H, prazole), 8.49 (s, $1 \mathrm{H}$, indole), 8.63 (s, $1 \mathrm{H}$, pyrimidine), 8.99 (s, 1H, $\mathrm{D}_{2} \mathrm{O}$ Exch., $\mathrm{NH}$ ), 11.82 (s, $1 \mathrm{H}, \mathrm{D}_{2} \mathrm{O}$ Exch., indole NH). MS: m/z (\%) 436 [M+, 0.04]. Anal. Calcd. For $\mathrm{C}_{23} \mathrm{H}_{16} \mathrm{~N}_{8} \mathrm{O}_{2}$ (436.40): C, 63.30; H, 3.70; N, 25.68. Found: $\mathrm{C}$, 63.45; H, 3.90; N, 25.50 .

1-(4-(1H-indol-3-yl)-6-(4-methoxyphenyl)pyrimidin-2-yl)6-thioxo-6,7-dihydro- $1 \mathrm{H}$-pyrazolo $[3,4-\mathrm{d}]$ pyrimidin- $4(5 \mathrm{H})$ one (14)

To a solution of compound $\mathbf{1 2}(10 \mathrm{~m} \mathrm{~mol})$ in dimethylformamide $(30 \mathrm{ml}), 20 \%$ potassium hydroxide solution (potassium hydroxide 1.68 $\mathrm{g}$, water $7 \mathrm{ml}$ ) and carbon disulfide $(5 \mathrm{ml})$ were added. The reaction mixture was heated under reflux for $15 \mathrm{~h}$, then poured into water and filtered off. The filtrate was precipitated with $\mathrm{HCl}(0.1 \mathrm{~N})$ and the solid product was collected, washed with water, dried, and recrystallized from ethanol/dimethylformamide to give pale brown crystals of compound $14 \mathrm{mp} 198-0^{\circ} \mathrm{C}$, yield 68\% IR: $v_{\max } / \mathrm{cm}^{-1} 3431(\mathrm{NH}), 3216$ $(\mathrm{NH}), 3148(\mathrm{NH}), 1727(\mathrm{C}=\mathrm{O}) .{ }^{1} \mathrm{H}$ NMR $\left(\mathrm{DMSO}-\mathrm{d}_{6}\right): \delta 3.84(\mathrm{~s}, 3 \mathrm{H}$, $\mathrm{OCH}_{3}$ ), 7.14-7.25 (m, 4H, Ar H's), 7.48 (d, 2H, J=8.6 Hz, Ar-H's), 8.26 
(s, $1 \mathrm{H}$, prazole), $8.28(\mathrm{~d}, 2 \mathrm{H}, J=8.6 \mathrm{~Hz}, \mathrm{Ar}-\mathrm{H} ' \mathrm{~s}), 8.32$ (s, $1 \mathrm{H}$, indole) 8.35 (s, 1H, pyrimidin), 8.90 (s, $1 \mathrm{H}, \mathrm{D}_{2} \mathrm{O}$ Exch., $\left.\mathrm{NH}\right), 9.93$ (s, $1 \mathrm{H}, \mathrm{D}_{2} \mathrm{O}$

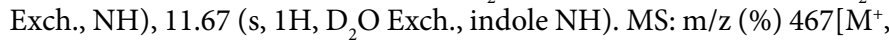
5]. Anal. Calcd. For $\mathrm{C}_{24} \mathrm{H}_{17} \mathrm{~N}_{7} \mathrm{O}_{2} \mathrm{~S}$ (467.50): C, 61.66; H, 3.67; N, 20.97. Found: $\mathrm{C}, 61.48 ; \mathrm{H}, 3.82 ; \mathrm{N}, 20.80$.

\section{1-(4-(1H-indol-3-yl)-6-(4-methoxyphenyl)pyrimidin-2-yl)- 4-chloro-1H-pyrazolo[3,4-]pyrimidine (15)}

A mixture of compound 11 (10 m mol) was heated in phosphorus oxychloride $(20 \mathrm{~mL})$ for $10 \mathrm{~h}$. The solution was cooled and poured into ice-water. The solid was filtered off, dried and purified on silica gel using chloroform /n-hexane (1:1) as eluent to give pale brown crystals mp 270-2 ${ }^{\circ} \mathrm{C}$, yield 64\% IR: $v_{\max } / \mathrm{cm}^{-1} 3433(\mathrm{NH}) .{ }^{1} \mathrm{H}$ NMR (DMSO-d $)$ : $\delta 3.81\left(\mathrm{~s}, 3 \mathrm{H}, \mathrm{OCH}_{3}\right), 7.09-7.26(\mathrm{~m}, 4 \mathrm{H}, \mathrm{Ar} \mathrm{H}$ 's), $7.43(\mathrm{~d}, 2 \mathrm{H}, J=8.7 \mathrm{~Hz}$, Ar-H's), 8.37 (d, 2H, J=8.7 Hz, Ar-H's), 8.41 (s, 1H, prazole), 8.58 (s, $1 \mathrm{H}$, indole), 8.63 (s, $1 \mathrm{H}$, pyrimidin), $8.87(\mathrm{~s}, 1 \mathrm{H}$, pyrimidin), 11.67 (s, $1 \mathrm{H}, \mathrm{D}_{2} \mathrm{O}$ Exch., indole NH). MS: $\mathrm{m} / \mathrm{z}(\%) 453\left[\mathrm{M}^{+}, 2.0\right]$. Anal. Calcd. For $\mathrm{C}_{24} \mathrm{H}_{16} \mathrm{ClN}_{7} \mathrm{O}$ (453.88): C, 63.51; H, 3.55; N, 21.60. Found: C, 63.35; $\mathrm{H}, 3.72 ; \mathrm{N}, 21.40$.

\section{1-(4-(1H-indol-3-yl)-6-(4-methoxyphenyl)pyrimidin-2-yl)- 1H-pyrazolo[3,4-d]pyrimidine-4-thiol (16)}

A solution of compound $15(10 \mathrm{~m} \mathrm{~mol})$ and thiourea $(10 \mathrm{~m} \mathrm{~mol})$ in dioxane $(40 \mathrm{ml})$ was heated at reflux for $4 \mathrm{~h}$. The formed precipitate was collected and dissolved in $\mathrm{NaOH}(20 \mathrm{ml}, 10 \%)$. Then the mixture was filtered off and the filtrate was precipitated with $\mathrm{HCl}(0.1 \mathrm{~N})$. The solid product was collected and recrystallized from ethanol to give pale brown crystals mp $157-9^{\circ} \mathrm{C}$, yield $60 \%$ IR: $v_{\max } / \mathrm{cm}^{-1} 3285(\mathrm{NH}), 3138$ (NH). ${ }^{1} \mathrm{H}$ NMR (DMSO-d $): \delta 3.80\left(\mathrm{~s}, 3 \mathrm{H}, \mathrm{OCH}_{3}\right), 7.29-7.33(\mathrm{~m}, 4 \mathrm{H}$, Ar H's), 7.39 (d, 2H, J=8.8 Hz, Ar-H's), 7.48 (d, 2H, J=8.8 Hz, Ar-H's), 7.99 (s, $1 \mathrm{H}$, prazole), 8.19 (s, $1 \mathrm{H}$, pyrimidin), 8.23 (s, $1 \mathrm{H}$, indole), 8.29 (s, $1 \mathrm{H}$, pyrimidin), 11.34 (s, $1 \mathrm{H}, \mathrm{D}_{2} \mathrm{O}$ Exch., indole $\left.\mathrm{NH}\right), 12.16$ (s, $1 \mathrm{H}$, $\mathrm{D}_{2} \mathrm{O}$ Exch., indole SH). MS: $\mathrm{m} / \mathrm{z}(\%) 451\left[\mathrm{M}^{+}, 18.0\right]$. Anal. Calcd. For $\mathrm{C}_{24} \mathrm{H}_{17} \mathrm{~N}_{7} \mathrm{OS}$ (451.50): C, 63.84; H, 3.80; N, 21.72. Found: C, 63.55; H, $3.72 ; \mathrm{N}, 21.56$.

\section{1-(4-(1H-indol-3-yl)-6-(4-methoxyphenyl)pyrimidin-2-yl)-} 4-(methylthio)-1H-pyrazolo[3,4-d]pyrimidine (17)

Compound 16 (0.005 mol.) in ethanol $(20 \mathrm{ml})$, and $10 \%$ sodium hydroxide solution $(5 \mathrm{ml})$ were treated with methyl iodide $(0.005 \mathrm{~mol}$.). The reaction mixture was refluxed for $6 \mathrm{~h}$, then cooled and poured into ice cold water. The separated solid was filtered off, dried and recrystallized from dioxane to give pale brown crystals $\mathrm{mp} 178-0^{\circ} \mathrm{C}$, yield 68\% IR: $v_{\text {max }} / \mathrm{cm}^{-1} 3285(\mathrm{NH}) .{ }^{1} \mathrm{H}$ NMR (DMSO-d $\left.\mathrm{d}_{6}\right): \delta 1.23(\mathrm{~s}, 3 \mathrm{H}$, $\left.\mathrm{SCH}_{3}\right), 3.89\left(\mathrm{~s}, 3 \mathrm{H}, \mathrm{OCH}_{3}\right), 7.03-7.27$ (m, $4 \mathrm{H}, \mathrm{Ar} \mathrm{H}$ 's), 7.39 (d, $2 \mathrm{H}, J=8.6$ $\mathrm{Hz}, \mathrm{Ar}-\mathrm{H}$ 's), 7.80 (s, $1 \mathrm{H}$, prazole), 8.11 (d, $2 \mathrm{H}, J=8.6 \mathrm{~Hz}, \mathrm{Ar}-\mathrm{H}$ 's), 8.17 (s, $1 \mathrm{H}$, indole), $8.26(\mathrm{~s}, 1 \mathrm{H}$, pyrimidin), $8.95(\mathrm{~s}, 1 \mathrm{H}$, pyrimidin), $9.90(\mathrm{~s}$, $1 \mathrm{H}, \mathrm{D}_{2} \mathrm{O}$ Exch., indole NH). MS: $\mathrm{m} / \mathrm{z}(\%) 465\left[\mathrm{M}^{+}, 18.0\right]$. Anal. Calcd. For $\mathrm{C}_{25} \mathrm{H}_{19} \mathrm{~N}_{7} \mathrm{OS}$ (465.5): C, 64.50; H, 4.11; N, 21.06. Found: C, 64.65; $\mathrm{H}, 3.97 ; \mathrm{N}, 21.26$.

1-(4-(1H-indol-3-yl)-6-(4-methoxyphenyl)pyrimidin-2-yl)4-hydrazinyl-1H-pyrazolo[3,4-d]pyrimidine (18)

\section{Synthesis of compound (18):}

- Method A: To a solution of compound 15 (1.67 g, $0.005 \mathrm{~mol}$ ) in dioxane $(30 \mathrm{ml})$, hydrazine hydrate $(2 \mathrm{ml})$ was added and the mixture was heated at reflux for $4 \mathrm{~h}$. The reaction mixture was cooled and poured into water and the separated solid was filtered off, dried and recrystallized from dioxane.

- Method B: Compound 17 (0.005 mol) was heated in hydrazine hydrate $(20 \mathrm{ml})$ for $2 \mathrm{~h}$, cooled then the reaction mixture was poured into water, neutralized with $\mathrm{HCl}$, filtered, dried and purified with column chromatography (silica gel) using chloroform: methanol (9:1), as eluent to give pale brown crystals mp $165-6^{\circ} \mathrm{C}$, yield $60 \%$ IR: $v_{\text {max }} / \mathrm{cm}^{-1} 3456\left(\mathrm{NH}_{2}\right), 3385$ $(\mathrm{NH}), 3224(\mathrm{NH}) .{ }^{1} \mathrm{H}$ NMR (DMSO-d $): \delta 3.83\left(\mathrm{~s}, 3 \mathrm{H}, \mathrm{OCH}_{3}\right)$, 7.02-7.16 (m, 4H, Ar H's), 7.21 (d, $\left.2 \mathrm{H}, J=8.8 \mathrm{~Hz}, A r-\mathrm{H}^{\prime} \mathrm{s}\right)$, 7.32 (d, 2H, $J=8.8 \mathrm{~Hz}$, Ar-H's), 7.91 (s, $1 \mathrm{H}$, prazole), 7.98 (s, $1 \mathrm{H}$, pyrimidin), 8.24 (s, $1 \mathrm{H}$, indole), 8.29 (s, $1 \mathrm{H}$, pyrimidin), 8.99-918 (brs, 3H, $\mathrm{D}_{2} \mathrm{O}$ Exch., $\left.\mathrm{NH}_{2}, \mathrm{NH}\right), 11.42$ (s, $1 \mathrm{H}, \mathrm{D}_{2} \mathrm{O}$ Exch., indole NH). MS: m/z (\%) 449 [M+1 1.63]. Anal. Calcd. For $\mathrm{C}_{24} \mathrm{H}_{19} \mathrm{~N}_{9} \mathrm{O}$ (449.47): C, 64.13; H, 4.26; N, 28.05. Found: C, $63.95 ; \mathrm{H}, 4.45 ; \mathrm{N}, 28.23$.

\section{Results and Discussion}

Through several years of research and cross referencing other related journals on the preparation of chalcones and their derivatives, chalcone compound $\mathbf{3}$ and thiopyrimidinone $\mathbf{4}$ were prepared as reported in literature [1].

The hydrazino-pyrimidine derivative $\mathbf{5}$ was synthesized by reacting the thiopyrimidinone $\mathbf{4}$ with hydrazine hydrate in refluxing alcohol, the structure of compound 5 was confirmed by IR, ${ }^{1} \mathrm{H}$ NMR, MS spectra and elemental analysis, where its IR revealed the absorption bands at $v_{\max }=3212$ for the $\mathrm{NH}_{2}$ and $3184,3109 \mathrm{~cm}^{-1}$ for the two $\mathrm{NH}$ groups, ${ }^{1} \mathrm{H}$ NMR spectrum gave the signals at $\delta=8.93-8.95$ as a broad singlet for $\mathrm{NH}_{2}$, hydrazine $\mathrm{NH}$ and at $11.65 \mathrm{ppm}$., for the indole $\mathrm{NH}$ respectively. MS spectrum substantiated it's exact molecular weight (cf. Scheme 1 and Experimental section).

The hydrazino-pyrimidine derivative $\mathbf{5}$ was used as an assorted precursor for the synthesis of some biologically active heterocycles, where the amino pyrazole carbonitrile compound $\mathbf{6}$ was synthesized by refluxing a 1:1 mixture of compound 5 in ethanol with ethoxymethylene malononitrile for $4 \mathrm{~h}$. The structure of compound $\mathbf{6}$ was confirmed by IR, MS, ${ }^{1} \mathrm{H}$ NMR and elemental analysis, where its IR spectrum gave the absorption bands at $v_{\max }=3312$ for $\mathrm{NH}_{2}, 3175$ for $\mathrm{NH}$ Indole and 2226 $\mathrm{cm}^{-1}$ for the $\mathrm{CN}$ group respectively, it's ${ }^{1} \mathrm{H}$ NMR substantiated an $\mathrm{NH}_{2}$ singlet at 8.86 and a singlet at $\delta=11.66 \mathrm{ppm}$ for $\mathrm{NH}$ indole.

The pyrazolo pyrimidine compound 7 was synthesized by heating an alcoholic solution of compound 5 (10.0 mmol.) with acetylacetone (10.0 mmol.) at reflux temperature for $5 \mathrm{~h}$. The FTIR spectrum of compound 7 disclosed the absorption bands at 3169 for NH indole, 1635 and $1575 \mathrm{~cm}^{-1}$ for $\mathrm{C}=\mathrm{N}$ groups respectively. ${ }^{1} \mathrm{H}$ NMR revealed $\mathrm{NH}$ indole singlet at $\delta=10.41$, singlet pyrimidine $\mathrm{H}$ at $\delta=8.95 \mathrm{ppm}$ and two singlets for the two $\mathrm{CH}_{3}$ protons respectively.

The pyrimidine pyrazolone compound $\mathbf{8}$ was obtained by refluxing a solution of compound $\mathbf{5}$ and ethyl acetoacetate in acetic acid for 6 h. The structure of compound $\mathbf{8}$ was deduced from its analytical and spectral data, which were in full agreement with the proposed structure (cf. Experimental section).

Furthermore, the hydrazino-pyrimidine derivative $\mathbf{5}$ was reacted with ethyl acetoacetate in excess to afford compound 9. IR spectrum of compound 9 revealed the absorption bands at $v_{\max }=3367$ and 1715 $\mathrm{cm}^{-1}$ characteristic for $\mathrm{NH}$ indole and $\mathrm{C}=\mathrm{O}$ groups respectively, ${ }^{1} \mathrm{H}$ NMR exhibited the $\mathrm{NH}$ indole singlet at $\delta=10.82$, two singlets at $\delta=1.23$ and 2.43 for $2 \mathrm{CH}_{3}$ protons and a singlet at $\delta=5.6 \mathrm{ppm}$ for pyranone $\mathrm{H}$ respectively (Scheme 2).

The 5-amino-1H-pyrazole-4-carbonitrile compound 6 was found to be an adequate, key starting for the synthesis of some other new heterocyclic compounds, where it was heated in formamide for $3 \mathrm{~h}$., to 

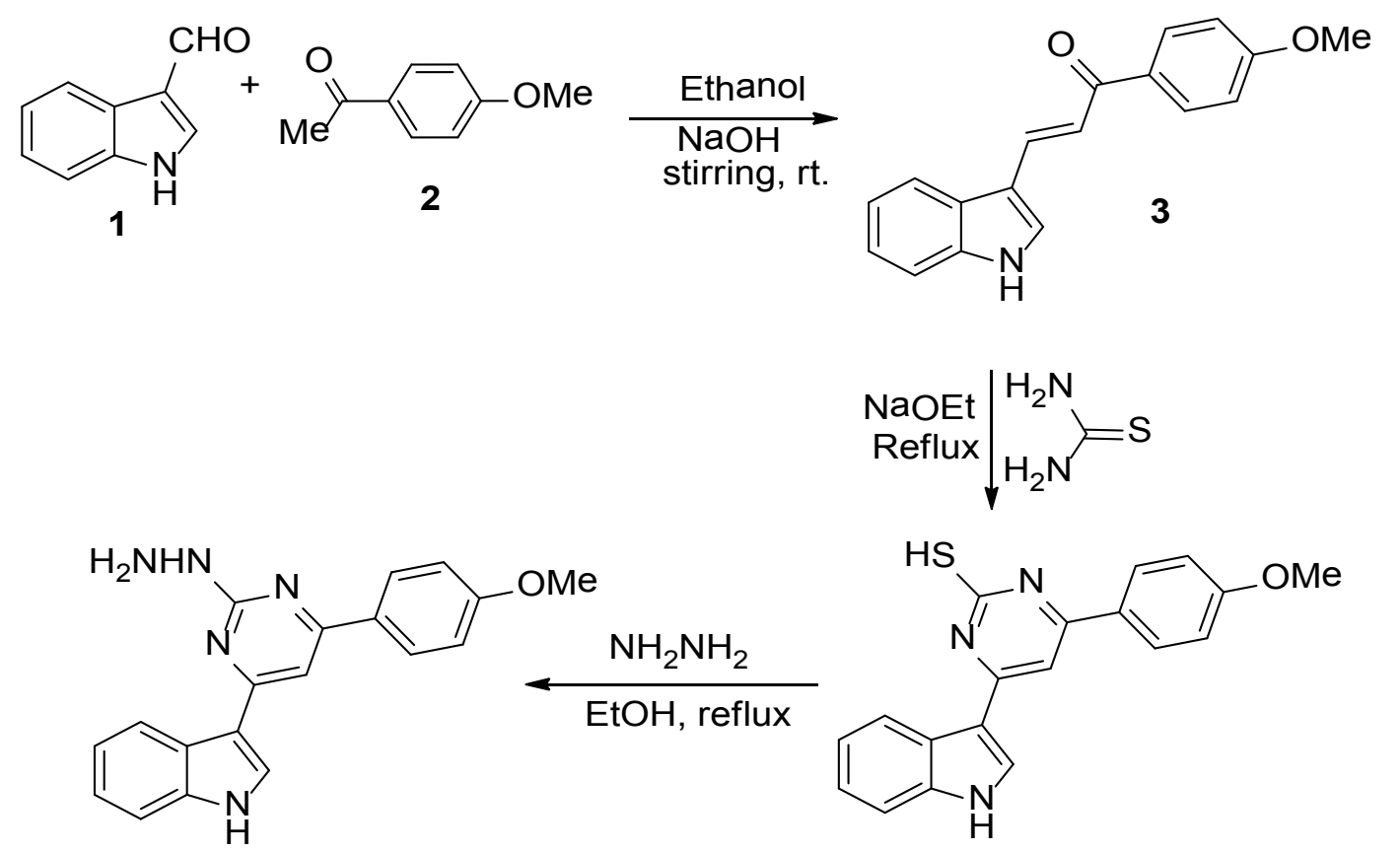

5<smiles>COc1ccc(-c2cc(-c3c[nH]c4ccccc34)nc(S)n2)cc1</smiles>

4

Scheme 1

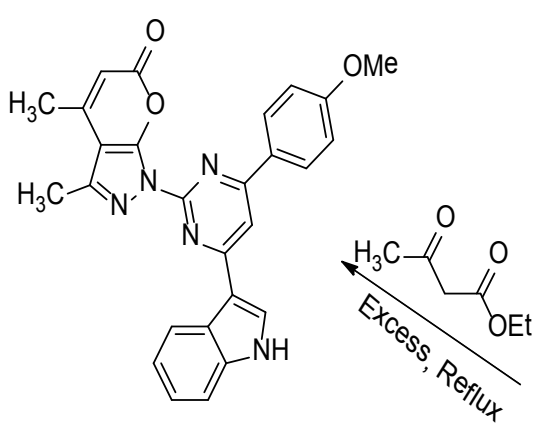

9

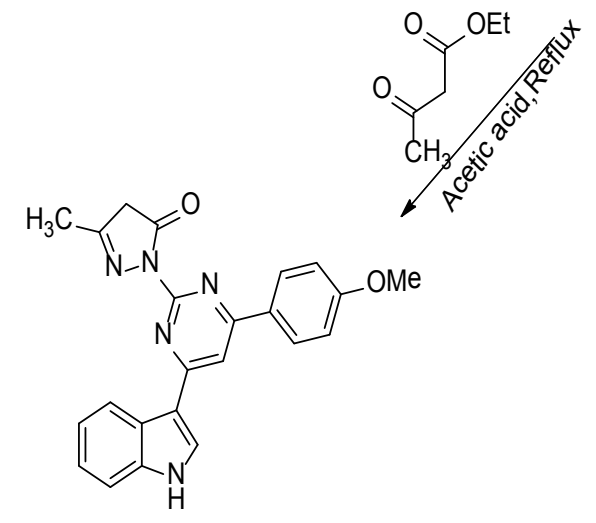

8

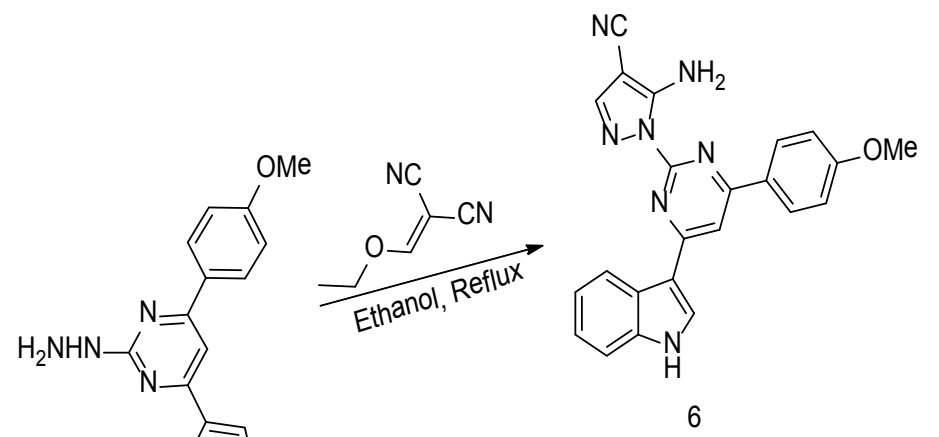<smiles>CC(=O)CC(C)=O</smiles><smiles>COc1ccc(-c2cc(-c3c[nH]c4ccccc34)nc(-n3nc(C)cc3C)n2)cc1</smiles>

Scheme 2 
produce compound 10. The structure of compound $\mathbf{1 0}$ was confirmed by its spectral and analytical data.

The pyrazolo pyrimidinone derivative 11 was obtained on one hand by refluxing compound $\mathbf{6}$ in excess formic acid and on the other hand by heating compound $\mathbf{1 2}$ under reflux condition in triethyl orthoformate. The IR spectrum of compound $\mathbf{1} 1$ substantiated the absorption bands of indole $\mathrm{NH}$, pyrimidinone $\mathrm{NH}$ and $\mathrm{C}=\mathrm{O}$ respectively at their prospective values. ${ }^{1} \mathrm{H}$ NMR, MS and elemental analysis gave the confirmatory data for compound 11 (cf. Scheme 3 and Experimental section).

Treatment of compound $\mathbf{6}$ with cold concentrated sulphuric acid portion wise and sterilizing on an ice bath for about an hour. afforded the pyrazolo carboxamide derivative 12. IR spectrum of compound 12 substantiated absorption bands at 3398 for pyrazole $\mathrm{NH}_{2}, 3267$ for amide $\mathrm{NH}_{2}, 3114$ for indole $\mathrm{NH}$ and 1640 for the amide $\mathrm{C}=\mathrm{O}$, it's ${ }^{1} \mathrm{H}$ NMR displayed three singlets at $\delta 8.48,9.14$ and $11.42 \mathrm{ppm}$ for $\left(\mathrm{D}_{2} \mathrm{O}\right.$ exchangeable) pyrazole $\mathrm{NH}_{2}$, amide $\mathrm{NH}_{2}$ and indole $\mathrm{NH}$ respectively.

Continuing a series of synthesis the pyrazolo carboxamide derivative 12 was transformed into the pyrazolo triazinone $\mathbf{1 3}$ by the addition of sodium nitrite solution to a suspended solution of $\mathbf{1 2}$ in concentrated hydrochloric acid at $0-5^{\circ} \mathrm{C}$ with stirring at room temperature.

Structure of compound $\mathbf{1 3}$ was approved by IR, ${ }^{1} \mathrm{H}$ NMR, MS measurements and elemental analysis (cf. Scheme 3 and Experimental section).
Refluxing a solution of compound $\mathbf{1 2}$ in dimethylformamide with $20 \%$ potassium hydroxide solution and carbon disulfide $(5 \mathrm{ml})$ afforded the thioxopyrazolo pyrimidinone derivative 14, which structure was deduced from its analytical and spectral data, (cf. Experimental section).

The pyrimidinone derivative compound $\mathbf{1 1}$ was heated in phosphorus oxychloride for $10 \mathrm{~h}$. to give compound $\mathbf{1 5}$ which in turn was transformed by reaction with thiourea into the pyrimidin-4-thiol compound 16.

Compound $\mathbf{1 6}$ in ethanol and 10\% sodium hydroxide solution was treated with methyl iodide then the reaction mixture was subjected to reflux affording the methylthiopyrazolo pyrimidine derivative $\mathbf{1 7}$.

Compound 18 could be synthesized by reacting both of compounds 15 and 17 with hydrazine hydrate. Structures 15, 16, 17, and 18 were based on their correct elemental analysis and spectral data (cf. Scheme 4 and Experimental section).

\section{Anti-proliferative activity}

The newly synthesized compounds 5, 7, 8, 9, 11, 12, 14 and 18 were tested for their in vitro antiproliferative activities in the National Cancer Institute (NCI), where a single dose $(10 \mu \mathrm{M})$ of the test compounds was used against 60 cell lines panel assay [15-19].

The data were reported as mean-graph of the percent of growth of the treated cells, and presented as percentage growth inhibition (GI\%) caused by the tested compounds (Table 1).<smiles>COc1ccc(-c2cc(-c3c[nH]c4ccccc34)nc(-n3ncc4c(=O)[nH]c(=S)[nH]c43)n2)cc1</smiles>

14<smiles>COc1ccc(-c2cc(-c3c[nH]c4ccccc34)nc(-n3ncc(C(=O)NN)c3NN)n2)cc1</smiles><smiles>COc1ccc(-c2cc(-c3cc(-c4c[nH]c5ccccc45)nc(-n4ncc(C#N)c4N)n3)nc(-c3cc(-c4ccc(OC)cc4)nc(-n4ncc5c(N)ncnc54)n3)n2)cc1</smiles>

6

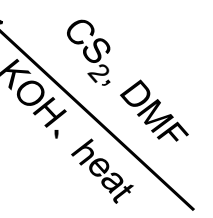

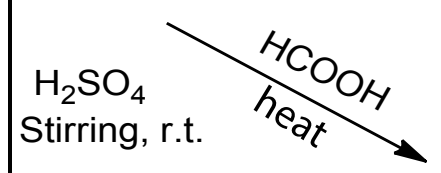
Stirring, r.t.<smiles>[3H]</smiles><smiles>COc1ccc(-c2cc(-c3c[nH]c4ccccc34)nc(-n3ncc(C(N)=O)c3N)n2)cc1</smiles>

12 

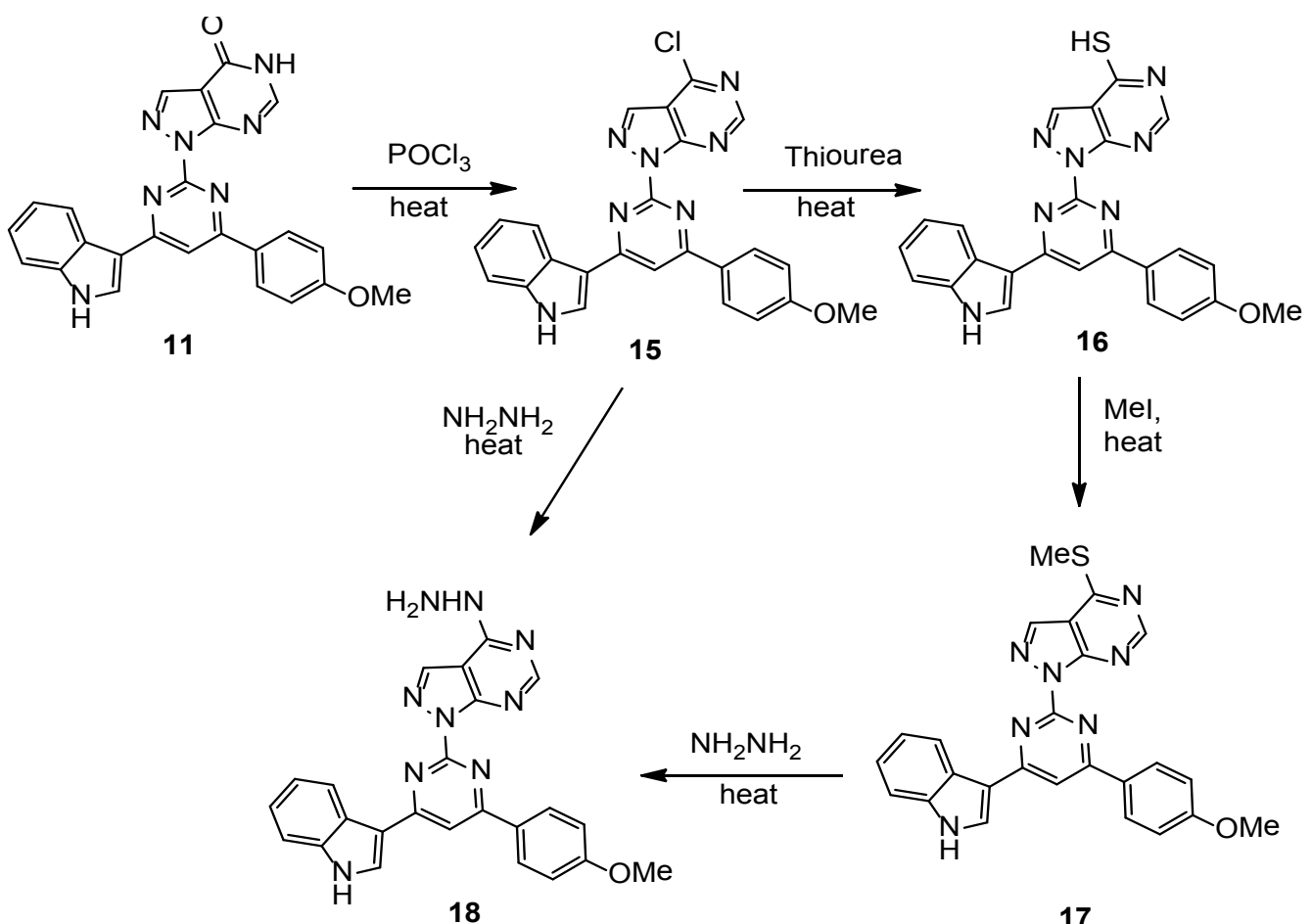

Scheme 4

It was found that all tested compounds displayed significant activities against the tested cell lines using $10 \mu \mathrm{M}$ concentration with positive cytotoxic effects (PCE) of $7 / 58,23 / 53,53 / 53,52 / 53, / 49 / 49$, $41 / 57,46 / 57$ and $46 / 58$ respectively (Table 2 ).

Compounds 7, 8, 9, 11, 12, 14 and 18 showed cytotoxic effects on the most of the cancer cell lines with mean growth inhibition percentage (MGI\%) of 10\%, 35\%, 44\%, 50\%, 19\%, 29\% and 34\% (Table 2) and compound $\mathbf{5}$ showed slight selective activity against HOP-62, NCI-H226, NCI- H522, SNB-75, OVCAR-4, PC-3 and MCF7 cancer cell lines with GI values of $13 \%, 20 \%, 11 \%, 28 \%, 11 \%, 11 \%$ and $21 \%$ respectively (Table 1).

With respect to broad spectrum antitumor activity, close examination of the data presented in Table 1 revealed that compounds 11, 14, and 18 are the most active derivatives showing effectiveness towards numerous cell lines belong to different tumor subpanels. Consequently, compounds 11, 14, and 18 were selected and tested against a panel of 60 different tumor cell lines at a $5-\log$ dose range [1-5].

These response parameters $\mathrm{GI}_{50}, \mathrm{TGI}$, and $\mathrm{LC}_{50}$ were calculated for each cell line, using the known drug 5 - Fluorouracil $(5-\mathrm{FU})$ as a positive control.

Compounds 11, 14 and 18 exhibited remarkable growth inhibitory activity pattern against renal cancer $\left(\mathrm{GI}_{50}=4.26,3.43\right.$ and $\left.12.30, \mu \mathrm{M}\right)$ non-small cell lung cancer $\left(\mathrm{GI}_{50}=5.65,3.92\right.$ and $\left.7.83 \mu \mathrm{M}\right)$ breast cancer $\left(\mathrm{GI}_{50}=4.16,4.16\right.$ and $\left.6.16 \mu \mathrm{M}\right)$ ovarian cancer $\mathrm{GI}_{50} 9.54,6.3 \mu \mathrm{M}$ and melanoma cancer $\left(\mathrm{GI}_{50}=9.58,4.24\right.$ and $\left.3.70 \mu \mathrm{M}\right) \mathrm{CNS}\left(\mathrm{GI}_{50}=5.43,2.50\right.$ and $3.38 \mu \mathrm{M})$ prostate cancer $\mathrm{GI} 9.58,4.24$ and $3.7\left(\mathrm{GI}_{50} 27.22,4.89\right.$ and $18.8 \mu \mathrm{M})$ respectively
It was found also that compounds 11, 14 and are about 1.5-3.0 fold more active than the positive control $5 \mathrm{FU}$, with $\mathrm{GI}_{50}(10.47,7.24$ and $14.12 \mu \mathrm{M})$ TGI $(58.8,36.30$ and $60.25 \mu \mathrm{M})$ and $\mathrm{LC}_{50}(>100,87.09$ and $95.49 \mu \mathrm{M}$ ) value respectively (Table 3 ).

Comparing the antitumor activities of compounds 11, 14 and 18 with those of Gefitinib and Erlotinib showed that compounds 11, 14 and 18 (Table 4) possess activities almost equal to or higher than those of Gefitinib and Erlotinib against most cell lines except non-small lung (EKVX and NCI - H522), melanoma (SK - MEL 28 ), ovarian cancer (IGROVI and $\mathrm{SK}-\mathrm{OV}-3$ ) renal cancer (ACHN and TK-10) and breast cancer (MDA-MB468) on the other hand compounds $\mathbf{8}$ and $\mathbf{1 2}$ showed selective activities toward CNS, renal and breast cancer cell lines, compound $\mathbf{9}$ gave selective activities toward leukemia cell lines, where compound 7 displayed moderate antitumor activities.

Regarding the activity toward individual cell lines, compounds $\mathbf{9}$, 12 showed selective activity against leukemia cell lines CCRF-CEM, $\mathrm{K}$ - 562, MOLT -4 and PRMI - 8226 with GI values of $26 \%, 22 \%, 19 \%$, $23 \%, 31 \%, 40 \%$ and $44 \%, 58 \%$, respectively.

Compound 12 revealed selective activities towards SR leukemia cell lines with GI values of $34 \%$ whereas compound 18 disclosed weak activity against k-562 and PRMI-8226 cell lines with GI values of $23 \%$ and $17 \%$.

Non-small lung A549/ATCC cell line proved to be selectively sensitive to $\mathbf{8}, \mathbf{9}, \mathbf{1 1}, \mathbf{1 2}, \mathbf{1 4}$ and $\mathbf{1 8}$ with GI values of $33 \% 34 \%, 72 \%$, $28 \%, 41$ and $58 \%$. In addition compounds $7, \mathbf{1 2}$, and 18 proved to be susceptible to the HOP-62, NCI-H226 and NCI/H522 cell lines with GI values of $33 \%, 34 \%, 91 \%, 45 \%, 69 \%, 73 \%$, 30\% lethal and $35 \%$, 


\begin{tabular}{|c|c|c|c|c|c|c|c|c|}
\hline \multicolumn{9}{|c|}{ \%Growth inhibition (GI\%) } \\
\hline 18 & 14 & 12 & 11 & 9 & 8 & 7 & 5 & Subpanel tumor cell lines \\
\hline & & & & & & & & Leukemia \\
\hline - & $\mathrm{nt}$ & 22 & $\mathrm{nt}$ & 26 & $\mathrm{nt}$ & nt & - & CCRF-CEM \\
\hline - & $\mathrm{nt}$ & - & $\mathrm{nt}$ & - & $\mathrm{nt}$ & $\mathrm{nt}$ & - & HL-60(TB) \\
\hline 23 & nt & 33 & $\mathrm{nt}$ & 19 & $\mathrm{nt}$ & $\mathrm{nt}$ & - & K-562 \\
\hline- & nt & 40 & $\mathrm{nt}$ & 31 & $\mathrm{nt}$ & $\mathrm{nt}$ & - & MOLT-4 \\
\hline 17 & $\mathrm{nt}$ & 58 & $\mathrm{nt}$ & 44 & $\mathrm{nt}$ & $\mathrm{nt}$ & - & PRMI-8226 \\
\hline- & nt & 34 & nt & nt & nt & $\mathrm{nt}$ & nt & SR \\
\hline & & & & & & & & Non-small cell lung cancer \\
\hline 58 & 72 & 41 & 34 & 28 & 33 & 13 & - & A549/ATCC \\
\hline nt & 25 & $\mathrm{nt}$ & 16 & nt & 17 & 11 & $\mathrm{Nt}$ & EKVX \\
\hline 91 & NT & 43 & 55 & - & - & 75 & 13 & HOP-62 \\
\hline 73 & 55 & 69 & $\mathrm{~L}$ & $\mathrm{nt}$ & 54 & 45 & 20 & $\mathrm{NCl}-\mathrm{H} 226$ \\
\hline $\mathrm{nt}$ & $\mathrm{nt}$ & $\mathrm{nt}$ & 76 & 46 & $\mathrm{nt}$ & 10 & - & HOP-92 \\
\hline- & 31 & - & 26 & 11 & 24 & - & - & $\mathrm{NCl}-\mathrm{H} 23$ \\
\hline 29 & 35 & 17 & 37 & 25 & 18 & 11 & - & $\mathrm{NCl}-\mathrm{H} 322 \mathrm{M}$ \\
\hline 52 & 32 & 19 & 43 & - & 36 & - & - & $\mathrm{NCl}-\mathrm{H} 460$ \\
\hline 35 & $\mathrm{nt}$ & $\mathrm{L}$ & 69 & 96 & 43 & 30 & 11 & $\mathrm{NCl}-\mathrm{H} 522$ \\
\hline & & & & & & & & Colon Cancer \\
\hline - & - & - & 12 & - & 17 & - & - & Colo 205 \\
\hline- & 23 & - & 25 & - & 10 & - & - & HCC-2998 \\
\hline 66 & 48 & 48 & 57 & 17 & 49 & 14 & - & HCT-116 \\
\hline 24 & 10 & 28 & 16 & - & 12 & - & - & HCT-15 \\
\hline 22 & 39 & 24 & 30 & - & 44 & - & - & HT29 \\
\hline $\mathrm{nt}$ & 23 & $\mathrm{nt}$ & 43 & 13 & 49 & - & - & KM12 \\
\hline 16 & - & 14 & 19 & - & 19 & - & - & SW-620 \\
\hline & & & & & & & & CNS Cancer \\
\hline 60 & 61 & - & 31 & 19 & 41 & 14 & - & SF-268 \\
\hline 41 & 55 & 34 & 21 & 25 & 16 & - & - & SF-295 \\
\hline 67 & 94 & 74 & 89 & 28 & $\mathrm{~L}$ & 46 & - & SF-539 \\
\hline 27 & 37 & - & 11 & 16 & 12 & - & - & SNB-19 \\
\hline $\mathbf{L}$ & $\mathrm{L}$ & 74 & $\mathrm{~L}$ & 45 & 47 & 23 & 28 & SNB-75 \\
\hline 56 & 94 & 30 & 43 & 20 & 45 & 25 & - & U251 \\
\hline & & & & & & & & Melanoma \\
\hline 29 & 32 & - & 39 & 18 & 26 & - & - & LOXIMVI \\
\hline 67 & 55 & 16 & 51 & 19 & 39 & 17 & - & MALME-3M \\
\hline 13 & 61 & 25 & 35 & - & 27 & 22 & - & M14 \\
\hline- & 24 & 12 & 33 & 11 & 22 & - & - & MDA-MB-435 \\
\hline 48 & 55 & 27 & 43 & 16 & 23 & - & - & SK-MEL-2 \\
\hline 27 & 40 & 30 & 25 & - & 22 & - & - & SK-MEL-28 \\
\hline 10 & 33 & 26 & 61 & 13 & 55 & - & - & SK-MEL-5 \\
\hline 43 & 80 & 39 & 39 & 11 & 31 & - & - & UACC-257 \\
\hline 15 & 24 & 47 & 47 & 34 & 57 & - & - & UACC-62 \\
\hline & & & & & & & & Ovarian Cancer \\
\hline- & 25 & - & 26 & - & 16 & - & - & IGROVI \\
\hline 33 & 31 & - & 57 & 12 & 23 & - & - & OVCAR-3 \\
\hline $\mathbf{L}$ & 52 & 39 & 77 & 37 & 19 & - & 11 & OVCAR-4 \\
\hline- & - & 12 & - & - & 15 & - & - & OVCAR-5 \\
\hline 71 & L & 27 & 59 & 21 & 32 & 55 & - & OVCAR-8 \\
\hline 17 & $\mathrm{nt}$ & 16 & 34 & 18 & 33 & - & - & NCI/ADR-RES \\
\hline 70 & 53 & 19 & 61 & - & 28 & 28 & - & SK-OV-3 \\
\hline & & & & & & & & Renal Cancer \\
\hline 28 & L & - & 57 & 17 & 42 & - & - & $786-\mathrm{o}$ \\
\hline 33 & L & 65 & 86 & 36 & 89 & 17 & - & A498 \\
\hline 47 & 34 & 55 & 63 & 22 & 43 & - & - & $\mathrm{ACHN}$ \\
\hline 35 & 16 & 37 & 18 & 28 & 24 & 12 & - & CAKI-1 \\
\hline 64 & 64 & 43 & 76 & - & 70 & 29 & - & RXF 393 \\
\hline 11 & 31 & 21 & 17 & 18 & 12 & - & - & SN12C \\
\hline
\end{tabular}




\begin{tabular}{|c|c|c|c|c|c|c|c|c|}
\hline - & $\mathrm{L}$ & - & 45 & - & 28 & - & - & TK-10 \\
\hline 29 & 52 & 26 & 29 & 55 & 38 & 23 & - & UO-31 \\
\hline & & & & & & & & Prostate Cancer \\
\hline 17 & 65 & 57 & 26 & 34 & 29 & - & 10 & PC-3 \\
\hline 17 & 46 & - & 20 & - & 28 & - & - & DU-145 \\
\hline & & & & & & & & Breast Cancer \\
\hline 23 & 18 & 30 & 30 & 16 & 30 & - & 21 & MCF7 \\
\hline 48 & 59 & 49 & 65 & 36 & 56 & 15 & - & MDA-MB-231/TCC \\
\hline 94 & 76 & 60 & 56 & 23 & 53 & 45 & - & HS 578T \\
\hline- & 87 & 27 & 47 & 12 & 69 & 28 & - & BT-549 \\
\hline 65 & 27 & 36 & 88 & 22 & 45 & - & - & $\mathrm{T}-47 \mathrm{D}$ \\
\hline 32 & $\mathrm{nt}$ & - & $\mathrm{nt}$ & - & nt & $\mathrm{nt}$ & - & MDA-MB-468 \\
\hline
\end{tabular}

nt=not tested, $\mathrm{G} /<10 \%$ compound proved to the cancer cell line.

Table 1: Percentage growth inhibitor (GI\%) of in vitro subpanel tumor cell lines at $10 \mathrm{UM}$ conc.

\begin{tabular}{|c|c|c|}
\hline \multicolumn{3}{|c|}{60 cell lines assay in one dose 10.0 UM conc. } \\
\hline PCE & MGI\% & Compd No. \\
\hline $7 / 58$ & 0 & 5 \\
\hline $23 / 53$ & 10 & 7 \\
\hline $53 / 53$ & 35 & 8 \\
\hline $41 / 57$ & 19 & 9 \\
\hline $52 / 53$ & 44 & 11 \\
\hline $46 / 57$ & 29 & 12 \\
\hline $49 / 49$ & 50 & 14 \\
\hline $46 / 58$ & 34 & 18 \\
\hline
\end{tabular}

Table 2: Mean growth inhibition percentage and positive cytotoxic effects of new compounds.

\begin{tabular}{|c|c|c|c|c|c|c|c|c|c|c|c|}
\hline \multicolumn{12}{|c|}{ Subpanel tumor cell lines } \\
\hline MG-MIDa & $\begin{array}{l}\text { Breast } \\
\text { cancer }\end{array}$ & $\begin{array}{l}\text { Prostate } \\
\text { cancer }\end{array}$ & $\begin{array}{l}\text { Renal } \\
\text { cancer }\end{array}$ & $\begin{array}{l}\text { Ovarian } \\
\text { cancer }\end{array}$ & Melanoma & $\begin{array}{c}\text { CNS } \\
\text { Cancer }\end{array}$ & $\begin{array}{l}\text { Colon } \\
\text { cancer }\end{array}$ & $\begin{array}{l}\text { NSC lung } \\
\text { cancer }\end{array}$ & Leukemia & Activity & $\begin{array}{c}\text { Compd } \\
\text { No. }\end{array}$ \\
\hline 10.47 & 4.16 & 27.22 & 4.26 & 9.54 & 6.56 & 5.43 & 51.9 & 5.65 & 84.5 & $\mathrm{GI}_{50}$ & 11 \\
\hline 58.8 & 67.09 & $b$ & 39.81 & 60.25 & 19.85 & 33.65 & $b$ & 42.65 & $b$ & TGI & \\
\hline b & $\mathrm{b}$ & $b$ & $\mathrm{~b}$ & b & $b$ & $\begin{array}{c}97.72 \\
2.5\end{array}$ & $\mathrm{~b}$ & $b$ & $\mathrm{~b}$ & $\mathrm{LC}_{50}$ & \\
\hline 7.24 & 4.16 & 4.89 & 3.47 & 6.3 & 4.24 & 84.7 & 36.43 & 3.92 & 86.09 & $\mathrm{GI}_{50}$ & 14 \\
\hline 36.30 & 27.28 & $\mathrm{~b}$ & 26.76 & 26.0 & 45.47 & 56.75 & 72.21 & 35.89 & $\mathrm{~b}$ & TGI & \\
\hline 87.9 & 70.79 & b & 98.0 & 93.11 & $\mathrm{~b}$ & 3.38 & 93.32 & 71.03 & $b$ & $\mathrm{LC}_{50}$ & \\
\hline 14.12 & 6.16 & 18.8 & 12.3 & 10.23 & 3.7 & 18.28 & 63.09 & 7.83 & b & $\mathrm{GI}_{50}$ & 18 \\
\hline 60.25 & 57.32 & $b$ & 45.49 & 87.09 & 79.03 & 69.50 & $b$ & 40.36 & $b$ & TGI & \\
\hline 95.49 & $b$ & $b$ & 97.72 & $b$ & $\mathrm{~b}$ & $b$ & $b$ & 94.40 & $b$ & LCO & \\
\hline 22.6 & 76.4 & 22.7 & 45.6 & 61.4 & 70.6 & 72.1 & 8.4 & $b$ & 15.1 & $\mathrm{GI}_{50}$ & $5-\mathrm{FU}$ \\
\hline b & $b$ & $b$ & $b$ & $b$ & $b$ & $b$ & $b$ & $b$ & $b$ & TGI & \\
\hline b & $b$ & $b$ & $b$ & $b$ & $b$ & $b$ & $b$ & $b$ & $B$ & $\mathrm{LC}_{50}$ & \\
\hline
\end{tabular}

Full panel mean graph midpoint $(\mu \mathrm{M})$; Compounds showed values $>100 \mathrm{UM}$

Table 3: Compounds 11, 14 and 18 mediam growth inhibitory (GI50 UM) total growth inhibitory (TGI, UM) and mediam lethal (LC50, UM) concentration of in vitro subpanel cell lines.

where compounds 8, 11 and $\mathbf{1 4}$ showed activities against NCI-H226 and NCI-H22, NCI-H323M and NCI-H460 cell lines with GIS values of $54 \%$, lethal $55 \%, 24 \%, 26 \%, 31 \%, 18 \%, 37 \%, 35 \%, 36 \%$, $43 \%$, and $32 \%$.

Compounds 9 and 11 showed strong activities against HOP-92 and NCI-H522 cell lines in 76\%, 46\%, 69\%, and 96\%, Meanwhile, compounds 12 and 18 showed certain activity against NCI-H3222-M and NCI-H460 cell lines in 17\%, 29\%, 19\% and 52\% respectively, compounds $\mathbf{9}, \mathbf{1 1}$, and $\mathbf{1 4}$ showed activities in 55\%, 25\% and $25 \%$ against HOP-62, EKVX and NCI-H322M cancer cells.

For the different cell lines of colon cancer, compounds 8, 11, 12, 14 and 18, showed GI values of 49\%, 57\%, 48\%, 48\%, 66\% against colon HCT- 122 and 44\%, 30\%, 39\%, 24\%, 22\% with colon HT29 cell lines, while compounds $\mathbf{1 1}$ and $\mathbf{1 4}$ demonstrated moderate activities against HCC- 2998 cancer cell lines with GI values $25 \%$ and $23 \%$ respectively, on the other hand compounds $\mathbf{1 2}$ and $\mathbf{1 8}$ verified sensitivity in $28 \%$ and $24 \%$ to colon HCT-15 cancer cell, compounds 8, 11, and 14 displayed modest activities against KM12 cancer cell with GI value 94\%, $43 \%$ and $23 \%$ respectively.

On screening the activities toward CNS cancer cell lines, compounds 7, 8, 9, 11, 14, 12, 18 showed strong potency against CNS cancers, SF-539, SNB-75 and U251 with GI values of 46\%, 89\%, 94\%, 


\begin{tabular}{|c|c|c|c|c|c|}
\hline \multicolumn{6}{|c|}{$G I_{50}(U M)$} \\
\hline Gefitinib & Erlotinib & 18 & 14 & 11 & Subpanel tumor cell lines \\
\hline \multicolumn{6}{|c|}{ Non-small cell lung cancer } \\
\hline 7.94 & 7.94 & 8.08 & 5.15 & 10.5 & A549/ATCC \\
\hline 0.05 & 0.05 & nt & 5.12 & 8.59 & EKVX \\
\hline 10.00 & 12.58 & 2.94 & 2.03 & 2.30 & HOP-62 \\
\hline 15.84 & 6.30 & 2.66 & 2.66 & 3.20 & $\mathrm{NCl}-\mathrm{H} 226$ \\
\hline 15.84 & 19.95 & 26.6 & 4.17 & 8.30 & $\mathrm{NCl}-\mathrm{H} 23$ \\
\hline 6.30 & 5.01 & nt & 6.72 & 7.24 & $\mathrm{NCl}-\mathrm{H} 460$ \\
\hline 6.30 & 1.00 & 11.10 & 3.65 & 4.63 & $\mathrm{NCl}-\mathrm{H} 522$ \\
\hline 7.94 & 6.30 & 1.9 & nt & nt & HOP-92 \\
\hline 0.08 & 0.05 & 70.4 & nt & nt & $\mathrm{NCl}-\mathrm{H} 322 \mathrm{M}$ \\
\hline 6.30 & 5.01 & 5.31 & $\mathrm{nt}$ & nt & $\mathrm{NCl}-\mathrm{H} 460$ \\
\hline \multicolumn{6}{|c|}{ Colon Cancer } \\
\hline 6.30 & 31.62 & $>100$ & 15.3 & $>100$ & Colo 205 \\
\hline 10.00 & 79.34 & $>100$ & 50.6 & $>100$ & HCC-2998 \\
\hline 7.94 & 5.01 & 4.35 & 6.74 & 3.38 & HCT-116 \\
\hline 3.98 & 50.11 & $>100$ & 16.6 & $>100$ & HT29 \\
\hline 7.94 & 63.09 & $>100$ & $>100$ & 29.9 & KM12 \\
\hline \multicolumn{6}{|c|}{ CNS Cancer } \\
\hline 7.94 & 19.95 & 4.21 & 3.57 & 6.91 & SF-268 \\
\hline 1.99 & 15.84 & nt & 1.94 & 7.01 & SF-295 \\
\hline 10.00 & 12.58 & 2.5 & 2.37 & 3.46 & SF-539 \\
\hline 12.58 & 3.98 & 3.17 & 2.93 & 21.4 & SNB-19 \\
\hline 6.30 & 12.58 & 1.9 & 1.57 & 1.82 & SNB-75 \\
\hline 10.00 & 19.95 & 7.06 & 3.18 & 3.93 & U251 \\
\hline \multicolumn{6}{|c|}{ Melanoma } \\
\hline 7.94 & 5.01 & 6.4 & 4.71 & 55.0 & LOXIMVI \\
\hline 3.16 & 5.01 & 4.73 & 3.3 & 4.07 & MALME-3M \\
\hline 5.01 & 6.30 & 24.4 & 16.1 & 8.38 & M14 \\
\hline 3.16 & 15.84 & $>100$ & 4.91 & 9.55 & MDA-MB-435 \\
\hline 12.58 & 12.58 & 4.40 & 3.41 & 3.38 & SK-MEL-2 \\
\hline 0.31 & 31.62 & 6.30 & 3.02 & 7.04 & SK-MEL-28 \\
\hline 3.98 & 15.84 & 32.4 & - & 3.67 & SK-MEL-5 \\
\hline 6.30 & 100.00 & 4.96 & 3.55 & 4.86 & UACC-257 \\
\hline 5.01 & 1.25 & 15.7 & 2.35 & 2.93 & UACC-62 \\
\hline \multicolumn{6}{|c|}{ Ovarian Cancer } \\
\hline 0.20 & 0.25 & 27.7 & 7.34 & 32.5 & IGROVI \\
\hline 5.01 & 3.16 & 5.05 & 7.68 & 9.36 & OVCAR-3 \\
\hline 7.94 & 19.95 & 3.95 & 2.11 & 3.41 & OVCAR-4 \\
\hline 10.00 & 19.95 & $>100$ & $>100$ & 58.0 & OVCAR-5 \\
\hline 10.00 & 7.94 & 5.01 & 3.46 & 4.42 & OVCAR-8 \\
\hline 12.58 & 6.30 & 9.25 & 3.30 & 8.97 & NCl/ADR-RES \\
\hline 0.63 & 0.39 & 4.75 & 2.91 & 3.06 & SK-OV-3 \\
\hline \multicolumn{6}{|c|}{ Renal Cancer } \\
\hline 7.94 & 5.01 & 4.17 & 3.51 & 3.2 & $786-0$ \\
\hline 0.4 & 1.58 & 15.8 & 1.75 & 1.01 & A498 \\
\hline 0.2 & 0.15 & 3.72 & 4.63 & 3.49 & $\mathrm{ACHN}$ \\
\hline 0.16 & 0.10 & $>100$ & 3.05 & 5.08 & CAKI-1 \\
\hline 5.01 & 6.3 & 3.48 & 2.55 & 2.24 & RXF 393 \\
\hline 6.3 & 6.3 & 78.0 & 4.70 & 5.24 & SN12C \\
\hline 0.10 & 0.10 & 7.43 & 4.06 & 5.58 & TK-10 \\
\hline 1.25 & 1.99 & 11.6 & 1.95 & 5.97 & UO-31 \\
\hline \multicolumn{6}{|c|}{ Breast Cancer } \\
\hline 10.0 & 10.0 & 32.0 & 7.93 & 9.98 & MCF7 \\
\hline 12.58 & 1.99 & 4.2 & 3.73 & 3.42 & MDA-MB-231/ATCC \\
\hline 10.0 & 6.3 & 2.18 & 2.46 & 3.23 & HS $578 T$ \\
\hline 7.94 & 39.81 & 5.02 & 2.02 & 2.98 & BT-549 \\
\hline 6.3 & 3. 16 & 7.04 & 6.57 & 4.01 & $\mathrm{~T}-47 \mathrm{D}$ \\
\hline 0.01 & 0.2 & 5.39 & 5.72 & 4.11 & MDA-MB-468 \\
\hline
\end{tabular}

Table 4: $\mathrm{GI}_{50}$ values (UM) of compounds 11, 14 and 18 Gefitinib and Erlotinib over the most cell lines of non-small lung cancer, colon cancer, CNS cancer, Melanoma, Ovarian cancer, Renal cancer and Breast cancer. 
$28 \%, 74 \%, 67 \%$, 23\%, 47\% lethal 74\% lethal, $25 \%, 45 \%, 43 \%, 94 \%, 20 \%$, $30 \%$ and $56 \%$, Compounds $\mathbf{9}, \mathbf{1 1}, \mathbf{1 4}$ and $\mathbf{1 8}$ showed GI values of $31 \%$, $61 \%, 19 \%, 60 \%, 21 \% 55 \%, 25 \%$ and $41 \%$ to CNS cancer SF- 268 and SF295 cell lines, respectively. CNS cancer SNB-19 proved to be sensitive to compounds 14 and 18 with GI values of $37 \%$ and $27 \%$ while compounds 8 and 12 showed certain potency to SF-268 and SF-295 cancer cells with GI values of $41 \%$ and $34 \%$ respectively.

On screening of the activities of tested compounds towards melanoma it was found that compounds 8,11 and 14 have the values of GI ranging from $22 \%$ to $80 \%$ against LOX, IMVI, MALME-3M, M14, MDA-MB-435, MDA-MB-435, SK-MEL-2, SK-MEL 28, SK- MEL-5 UACC-257 and UACC-62 cell lines respectively.

Compound 7 showed moderate activities against M14 cell line, whilst compounds $\mathbf{9}$ and $\mathbf{1 2}$ possessed activity against UACC-62 cell line with GI values of $34 \%$ and $47 \%$, Melanoma SK-MEL-2, SK-MEL-28 UACC-257 cell lines were found to be sensitive to compounds $\mathbf{1 2}$ and $\mathbf{1 8}$ in as shown in Table 1 , at the same time compound $\mathbf{1 8}$ was active towards LOX IMVI and MALME-3M cell lines GI, $29 \%$ and $67 \%$, and compound $\mathbf{1 2}$ has slight activity against SK-MEL-5 cell line with GI value $26 \%$.

The results obtained toward ovarian cancer cell lines revealed that compounds 7, 8 and $\mathbf{1 1}$ showed moderate activities against ovarian OVCAR-8 and SK-OV-3 cell lines, compounds 8, 11 and 14 were effective towards OVCAR-3 and OVCAR-4 cell lines while compounds 9 and 12 showed different activities against OVCR-8 OVCAR- 4 cell lines respectively (cf, Table 1).

The reactivity of compounds 8, 11, 14 and 18 against Ovarian NCI3/ADR-RES, IGR-OVI, OVCAR- 8 and OVCAR-4, OVCAR- 3 and SK-OV-3 cell lines were also measured and recorded in Table 1.

In case of renal cancer, compounds 8, 11, 14 and 18 substantiated different activities against 786-O, A498, ACHN, CAKI-1, RXF393, SNI2C, TK-10 and UO-31 cell lines with GI values from $24 \%$-lethal. Renal A498, ACHN, CAKI-I, SN12C and UO-31 cell lines were found to be sensitive to compounds 9 and 12 with GI values of $36 \%, 65 \%, 22 \%$, $55 \%, 28 \%, 37 \%, 18 \%, 21 \%, 55 \%$ and $26 \%$ respectively, whereas RXF393 cell line was affected by compounds 7 and 12 with GI values of $29 \%$ and $43 \%$ respectively.

Prostate PC-3 and DU-145 cell lines were proved to be selectively sensitive to compounds $\mathbf{8 , 1 1}$ and $\mathbf{1 4}$ with GI values of $29 \%, 26 \%, 65 \%$, 28\%, 20\% and 46\% respectively, while compounds 9 and 12 possessed selective activity towards PC-3 cell line with GI values of $34 \%$ and $57 \%$ respectively.

Regarding the breast cancer; MCF7, MDA-MB-231/ATCC, HS 578T, BT-549, T-47D cell lines were found to possess convincing response to compounds $8,9,11,12$ and 18 with GI values ranging from $23 \%$ to $94 \%$, compound 7 showed GI effectiveness against breast HS $578 \mathrm{~T}$ and BT-549 cell lines with values of $45 \%$ and $28 \%$, additionally compound 18 gave selective activity against breast MDA-MB-468 cell line with GI values of $32 \%$.

\section{Conclusion}

The authors herein endeavored to design and synthesize new pyrazolopyrimidine derivatives and screen some of these compounds for their anti-proliferative activity.

\section{Acknowledgements}

The authors would like to express their great appreciation to the staff at Micro-analytical Center of Cairo University and the National Cancer Institute (NCI) in Egypt for their assistance with the collection of data.

\section{References}

1. Nassar E (2010) Synthesis, (in vitro) antitumor and antimicrobial activity of some pyrazoline, pyridine, and pyrimidine derivatives linked to indole moiety. $J$ of Amer Sci 6: 338-347.

2. Nassar E, Abdel-Aziz HA, Ibrahim HS, Mansour AM (2011) Synthesis of Diarylpyrazoles Containing a Phenylsulphone or Carbonitrile Moiety and their Chalcones as Possible Anti-Inflammatory Agents. Sci Pharm 79: 507-524.

3. Nassar E, El-Farargy AF, Abdelrazek FM (2015) Synthesis of some novel cyclooctane fused heterocycles with anticipated biological activities. J Heterocyc Chem 52: 1395-1399.

4. Hamad Elgazwy AS, Nassar E, Zaki MY (2012) Synthesis, Biologica Evaluation of Some 2,3-dihydropyrazoles and Thiazoles as Anti-inflammatory and Antibacterial Agents. Organic Chem Curr Res 1: 5

5. Nassar EM, Abdelrazek FM, Ayyad RR, El-Farargy AF (2016) Synthesis and Some Reactions of 1-aryl-4-acetyl-5-methyl-1,2,3-triazole Derivatives with Anticonvulsant Activity. J of Mini Rev in Med Chem 16: 5.

6. Asiri AM, Khan SA (2011) Synthesis and Anti-Bacterial Activities of a BisChalcone Derived from Thiophene and Its Bis-Cyclized Products. Molecules 16: 523-531.

7. Kumar D, Kumar NM, Akamatsu K, Kusaka E, Harada H, et al. (2010) Synthesis and biological evaluation of indolyl chalcones as antitumor agents. Bioorg Med Chem Lett 20: 3916-3919.

8. Ducki S, Forrest R, Hadfield JA, Kendall A, Lawrence NJ, et al. (1998) Potent antimitotic and cell growth inhibitory properties of substituted chalcones. Bioorg Med Chem Lett 8: 1051-1056.

9. Edenharder R, Petersdorff IV, Rauscher R (1997) The inhibition by flavonoids of 2-amino-3-methylimidazo[4,5-f]quinoline metabolic activation to a mutagen: a structure-activity relationship study. Mutat Res 279: 21-32.

10. Pandeya SN, Sriram D, Nath G, DeClercq E (1999) Synthesis, antibacterial, antifungal and anti-HIV activities of Schiff and Mannich bases derived from isatin derivatives and $\mathrm{N}$-[4-(4'-chlorophenyl)thiazol-2-yl] thiosemicarbazide. Eur J Pharm Sci 9: 25-31.

11. Biradar JS, Sasidhar BS, Parveen R (2010) Synthesis, antioxidant and DNA cleavage activities of novel indole derivatives. Eur J Med Chem 45: 4074-4078.

12. Nowakowska $Z$ (2007) A review of anti-infective and anti-inflammatory chalcones. Eur J Med Chem 42: 125-137.

13. Devi JM, Ali KS, Venkatraman VR, Ramakrishnan SK, Ramachandran KAA (2005) Study on the thermal properties of cinnamoyl chalcones. Therochim. Acta 438: 29-34.

14. Ando M, Nishida H, Nishino Y, Ohbayashi M, Ueda K, et al. (2010) Carbonyl side-chain of catechol compounds is a key structure for the suppression of copper-associated oxidative DNA damage in vitro. Toxicol Lett 199: 213-217.

15. Grever MR, Schepartz SA, Chabner BA (1992) The National Cancer Institute: cancer drug discovery and development program. Semin Oncol 19: 622-638.

16. Shoemaker $\mathrm{RH}$ (2006) The $\mathrm{NCl} 60$ human tumour cell line anticancer drug screen. Nat Rev Cancer 6: 813-823.

17. Monks A, Scudiero D, Skehan P, Shoemaker R, Paull K, et al. (1991) Feasibility of a high-flux anticancer drug screen using a diverse panel of cultured human tumor cell lines. J Natl Cancer Inst 83: 757-766.

18. Alley MC, Scudiero DA, Monks A, Hursey ML, Czerwinski MJ, et al. (1988) Feasibility of drug screening with panels of human tumor cell lines using a microculture tetrazolium assay. Cancer Res 48: 589-601.

19. Boyd MR, Paull KD (1995) Some practical considerations and applications of the national cancer institute in vitro anticancer drug discovery screen. Drug Dev Res 34: 91-109. 